\title{
The Main Proposals for the Content of Moral Theology in the Light of the Documents of the Council's Renewal*
}

In the Council Decree on the Formation of Priests, we find the following statement on moral theology: "Particular attention must be paid to the improvement of moral theology, whose scientific interpretation, nourished to a greater extent by the doctrine of Scripture, shows the sublimity of the vocation of the faithful in Christ and their duty to bear fruit in love for the life of the world" (OT 16). This clear indication is complemented by other statements by the Second Vatican Council concerning the adapted renewal of the theological sciences ${ }^{1}$. The issue of the renewal of theology in the spirit of the Council was also the subject of several statements by Pope Paul VI in recent years ${ }^{2}$.

In addition to special statements on studies and theological sciences, many of the indications of importance for the renewal of moral theology can be found indirectly in the documents of the Teaching Church. In this case, it is not only the Council's resolutions, but also other, especially post-conciliar, documents of the Church's magisterium. All these documents are referred to collectively as the Council's renewal documents. In the present paper I intend to indicate the postulates regarding the content of moral theology, which stem from these documents.

* STV 6(1968)1.

1 We find them in the following documents of the Council: DV 23f; GS 44.62; UR 4.5.10.17; OT 13-18; AG 22; GE 11.

2 Cf. Allocutio in Gregoriana Pontificia Studiorum Universitate habita, in: AAS 56(1964), 363-367; Allocutio coram VI Congressu Thomistico Internationali, in: AAS 57(1965), 788-792; Epistula Apostólica Alma Parens, in: AAS 58(1966), 609-614; Epistula ad card. Pizzardo Cum iam (de theologia Concilii Vaticani II), AAS 58(1966), 877-881; Allocutio ad eos, qui interfuerunt Conventui... de theologia Concilii Vaticani II, AAS 58(1966), 889-896. 


\section{The Theology of God's Call}

The answer to the question whether the main task of moral theology is to give a theologically valid lecture on the Christian doctrine of religious-moral life in the light of God's revelation, or whether it is to develop a set of norms of conduct, is essential in order to determine the proper object of moral theology.

\section{Obligation or Vocation}

It seems unambiguous to point to this issue in the statement of Vaticanum II quoted in the introduction. The scientific lecture of moral theology according to the Council is to show "the sublimity of the vocation of believers in Christ and their duty to bear fruit in love for the life of the world" (OT 16).

Showing the sublimity of the vocation in Christ undoubtedly postulates the presentation of the ideal of Christian morality, while showing the obligation to bear fruit assumes taking into account the aspect of moral obligation. So, we see, that the conciliar indication does not go along the line of adequately separable "or-or;" the description of the ideal of moral life or the definition of moral duties. On the contrary, it dictates that a scientific lecture on moral theology should show both aspects of moral life under consideration ${ }^{3 .}$ Therefore, one cannot limit oneself to a description of Christian morality without considering the normativity of the principles of moral behaviour. In turn the displaying of binding principles of morality requires in turn a rational justification of these principles.

The analysed statement of the Council indicates not only the need to include in the lecture of moral theology both the presentation of the ideal of morality and normativity, but also draws attention to the approach to the issue of moral life. It has been included by the Council in the categories of God's call and the duty of life's commitment on the part of man - "the duty to bear fruit in love for the life of the world" (OT 16, cf. LG 11-13.34-34; GS 18.25.92; GE 1). In this way, the Council authorized, as it were, the concept of Christian morality

\footnotetext{
3 In the absence of comprehensive documentation of the statements of Vaticanum II, it is not possible at least for the time being to determine what the Fathers meant by the term: "scientific lecture" (scientifica expositio). It undoubtedly refers to the teaching of moral theology. It was used in the Decree on the Formation of Priests. It seems, however, that indirectly at least it is also an indication for research work in the field of moral theology, since the implementation of the intended teaching depends on the results of the current state of research, and the subject of teaching moral theology depends on the concept of this scientific discipline.
} 
as the morality of the dialogue between man and God in life. The specific feature of this dialogue is that it is a responsive morality; the morality of man's life response to God's call. The initiative of this dialogue belongs to God (cf. 1) 4:10) and manifests itself precisely in the category of invocation (cf. Rom 1:1.6.7; 8:28.30; 1Cor 1:2.9; Gal 1:6; 1P 2:9). It is not an optional call but a morally binding call for a human being to respond to life's response. Moral conduct, therefore, is conditioned by God's call, which is the result of God's saving plan, and has its justification not only in the work of redemption but also in the work of creation.

The moral theology can thus be described as the theology of God's call and man's response to life. Since the obligation to engage in life's work is indeed conditioned by God's broadly understood vocation, it seems justified to believe that the primary object of moral theology is the morally binding Christian vocation. The religious and moral duties connected with the postulate of a life answer are, as we have stated, dictated by God's call, which is manifested both in the sublimity of the Christian vocation and in the gift of man by God ${ }^{4}$.

\section{Vocation in Christ}

The task of moral theology in the spirit of Council renewal does not consist primarily in the scientific elaboration of a list of principles and commandments to be followed in the Christian life. Such an approach could distort the true image of Christian morality. After all, it does not reveal the inner dynamism and vital signs of personalization and dialogue of the religious-moral life of a Christian. It could also give the impression that Christian morality, while humanistic, nevertheless places more emphasis on respect for impersonal law and order than on personal involvement. In a word, it would seem that Christian morality is legalistic and minimalistic, and not personalistic and responsorial.

Nor does it meet the requirements of the Council's renewal with a view to Christian morality that does not reveal the proper place of Jesus Christ in the dialogue between God's religious and moral life and man. It is not enough to show the figure of Jesus Christ as a lofty teacher and a personal model to follow. Such an approach is too neutral and moralistic. Nor does it reflect the characteristic features of the Christian concept of morality.

Undoubtedly, moral theology, in the spirit of Council renewal, will show Christ as a great teacher of morality and an unrivalled model of moral life.

4 Cf. J. Puchs, Theologia moralis perficienda. Votum Concilii Vaticani II, Periodica de re morali, canonica, liturgica, 55(1966), 501. 
Above all, however, he will point out that God's call is made in Jesus and that man's answer to life is also to be made in Jesus Christ.

In light of the revealed truth, man reaches God only through Jesus Christ (cf. 1Tim 2:5). So we are to be like Christ (cf. J 13:12-15; 15:10; Rom 6:1-11; 15:1-37; Phil 2:7; 1J 2:6). What is more, we will follow Jesus Christ (cf. Mk 1:16-20; 2:15; 3:13; Lk 9:59). This is more than just an outward imitation. It means sharing the fate of Christ, and thus the life relationship of man with Christ the Saviour (cf. Mt 10:17f; J 12:26). It can be said, therefore, that man's attitude towards God manifested in his religious and moral life is a postulate of life in Christ (cf. Rom $7: 6$; 8:2.14-16; 1Cor 1:30). He is not only the primordial and the norm, but also the foundation - the source - of Christian life, which is to be a part of his life (cf. Rom 8:29; Col 1:15-20) $)^{5}$.

The place of Jesus Christ in Christian life and morality is strongly marked in the Council documents (cf. LG 6.7.41-43; 47; AG 24; OT 8; PC 2). The Council speaks clearly of the Mystery of Christ, in which the whole history of humanity is summarised (cf. OT 14), both the human community and the life of the individual. Hence the postulate of Christocentrism is moral theology. This does not contradict either anthropocentrism or theocentrism because we are Christ and Christ of God (cf. Rom 6:11; 1Cor 3:23-15:8). On the contrary, in the Christocentric approach, the postulate of theocentrism and the postulate of anthropocentrism consistent with the notion of true humanism are guaranteed.

The phrase itself: "the calling of the faithful in Christ" (OT 16) points to the interconnection of these seemingly contradictory points of reference in Christian morality. In fact, much depends on the proper linkage of these three aspects. After all, God's plan of salvation aims precisely at making man in Jesus Christ a child of God and, through his religious and moral life, in his relationship with Christ in the Holy Spirit, he received participation in the life of the Divine Trinity.

So in such a manner God is the ultimate goal of man in the religious-moral plane. Man is the subject of moral values and norms. His conduct is an analogy which gives priority to the notion of what is moral. A characteristic feature of this behaviour is the birthmark of Christ - "in Christ." Therefore, moral theology, according to the Council, should show "the sublimity of the vocation of the faithful in Christ" (OT 16).

5 Cf. ibid., 502-505; S. Moysa, Pastoral and Ecumenical Character of the Second Vatican Council and the Development of Catholic Theology, STV 3(1965), 446-456; Sz. Sobalkowski, Teologia moralna i jej stanowisko chrystocentryczne w całości nauk teologicznych, AK 49(1948), 313-331. 


\section{Dimensions of the Vocation}

The place of Jesus Christ in moral theology, and therefore the Christological birthmark of the theological elaboration of Christian morality in the spirit of conciliar renewal, is clearly dictated by the vocation of man by God in Christ. This is what summarises the sublimity of the Christian vocation.

The Council documents reveal the dimensions of the vocation of the faithful in Christ: it is a call to fraternal communion with God and with people (cf. GS 18.92); a vocation that applies to all people (cf. LG 13); the universal vocation to holiness (cf. LG 32-12) salvation (cf. LG 41).

Within the framework of moral theology, therefore, it is necessary, according to the revealed word of God, to show the Christian perspective of this salvation, especially the eschatological perspective. For the Christian vocation is exercised on the basis of human history, in the pilgrim Church, in the community of the People of God waiting for parishion, but always with a keen awareness that the renewal of the world is already taking place, because a new era has already come into being (cf. LG 48). It is also important to clearly emphasize the communal character of man's vocation in God's plan (cf. GS 24) and the fact that human solidarity reaches its perfect form in the Incarnate Word (cf. GS 32).

Supernatural salvation is a gift from God and has a religious character. It is the ultimate goal, and an indispensable condition for this goal is the proper religious and moral life of man (cf. LG 11-13 31-34; OP 6; DB 15; PC 2; GE 2). In this interconnection between salvation and moral life, the Christian approach to morality in relation to religion is revealed. Moral life, however, becomes adequate for the purpose of supernatural salvation if it is animated by supernatural love (vita caritate formata).

The vocation of the faithful in Christ is both a gift and a moral imperative that becomes concrete in the daily life of a Christian. In light of this vocation, all that makes up his life, both in the natural order and in the supernatural order, takes on value. On the other hand, because of man's frailty and sinfulness, the Christian vocation presupposes not only continuous moral perfection, but also continuous conversion (cf. Mt 16:24) - the postulate of penance (metanota). Moral theology as a science of the religious-moral life of a Christian should reveal the fundamental significance of penance for this life. For in repentance the essential conditions for the continuous renewal of the Christian life are summarised.

6 On the territory of Polish moral theology, J. Woroniecki already drew attention to this duty twenty years ago, while sketching the program of the theology of Christian life, cf. J. Woroniecki, Nauka o doskonałości chrześcijańskiej w seminariach duchownych, AK 48(1948), 347. 
A thorough study of the question of penance in the spirit of the Council's renewal can be found in the Apostolic Constitution of Paenitemini ${ }^{7}$. It is a valuable source for the theological-moral treatise on penance. He points to the Christological justification for Christian penance ${ }^{8}$. By introducing a new discipline of the fast, the Constitution presents it in the perspective of the universal obligation of penance under God's law.

The Apostolic Constitution Indulgentiarum doctrina is also a valuable post-conciliar guideline in relation to the question of penance ${ }^{910}$. Particular attention should be paid to the strong emphasis on the need for moral commitment as a prerequisite for obtaining indulgences. In addition, the new discipline of indulgences is based on the theology of sin and penance.

It seems that one of the Council's demands to moral theology is to deal with the problem of sin against the background of the obligation of internal conversion to God. Consideration of the issue of penance within the framework of moral theology is also a postulate resulting from the concern to ensure that the doctrine of religious and moral life ensures the essential mark of the cross of Christ. Paul VI points out that in the evangelical words of the call: "Repent and believe the gospel." (Mk 1:15) the ideal of the Christian life is briefly summarised ${ }^{11}$.

The Christian morality which has its justification in God's call is, according to the Council, an ideal of religious-oral life for all people, not just for Christians. Such is the "model" of morality revealed by God. All people participate in it not only as vocations to live in Christ, but also through the supernatural bonds that unite them with God and with the community of the People of God. Moreover, non-believers are not devoid of the gifts of grace, so they can respond to God's call to a certain extent (cf. LG 8,16; GS 22; AG 3) ${ }^{12}{ }^{13}$.

7 Cf. Paulus VI, “Paenitevnani,” AAS 58(1966), 177-198.

8 Cf. Ibid., 177.179.181.

9 Cf. Paulus VI, “Indulgentiarum, doctrina,” AAS 59(1967), 5-24.

10 Standard 7: In connection with the conditions of plenary indulgence, we read: "Requiritur insuper ut excludatur omnis affectus erga quodcumque peccatum etiam veníale." Ibid., 22; Standard 12: "Divisio indulgentiarum in personales, reales et locales, non amplius adhibetur, quo clarius constet indulgentiis ditari christifidelium actiones, quamvis cum re vel loco interdum coniungantur." Ibid., 22.

${ }_{11}$ "Quae verba totius vitae christianae quasi summa sunt et complexion." Paulus VI, "Paenitemini," 179.

12 Cf. J. Fuchs, art. cit., $510 f$.

13 Cf. Sacra Congregatio Rituum, Instructio de cultu Mysterii Eucharistici, 13, L'Osservatore Romano, 31 V 1967, 3. 


\section{Place of the Sacred Sacraments}

The Christian vocation includes God's call to life's response. God calls us in Jesus Christ. Our response will take place in our life's contact with Christ. Hence the need for a religious-moral commitment to the Mystery of Christ, which permeates all human history and continues today, above all, in the Church of Christ (cf. OT 14). The normal way of doing this is through the sacred sacraments. This is clearly indicated in the documents of the Council (cf. LG 7.11; SC 6). In connection with the sacraments, attention has been drawn to the issue of the sacraments, so far overlooked in theology, as signs of faith, which "not only assume faith, but by means of words and things give it growth, strengthen it and express it" (KL 59, cf. 33). The value of personal involvement in the sacramental life, i.e. the ex opere operantis case (cf. KL 10-12) was also highlighted.

The religious and moral life of a Christian is marked by the sacraments of initiation: Baptism, Confirmation, Eucharist. Baptism as the foundation of a life-giving relationship with Christ and the Church; Confirmation as an effective sign of the strengthening of the Christian life on the path, with particular emphasis on the responsibility for the life in human society and the sacralization of the world; the Mystery of the Eucharist as the centre not only of the official worship of God but also of the Christian life (cf. KL 10.47) ${ }^{14}$.

The Eucharist, as evidenced by the conciliar documents of the Council, fully realizes the sacramental union of the Christian with Christ and with the whole Mystical Body (cf. LG 7.11; SC 6.47). It also reveals the sacralisation of temporal values because in this sacrament "the gifts of nature, man-made, are transformed into flesh and blood of glory" (GS 38). The Sacrament of Penance is a solemn and effective sign of reconciliation with God and the Church (cf. LG 11; OP 5).

In light of the Council's data, it seems indispensable to include the issue of sacraments in moral theology. However, this is a moral issue of the sacraments, which until now has been mostly overwhelmed by canonical and pastoral issues in textbook studies of moral theology. It is therefore necessary to demonstrate the value and necessity of the sacraments of Saint John of God for the proper development of a full human life, since they sanctify the proper use of material things (cf. SC 61), they show the passing figure of the world (cf. LG 48), they foretell and imagine a new heaven and a new earth (cf. LG 35).

\footnotetext{
14 "Eucharisticum mysterium sacrae Liturgiae immo totius christianae vitae, est vere centrum." Ibid. 1. Cf. 6.7.
} 
Due to the importance of the sacraments for Christian morality, which is essentially sacramental morality, the issue of the sacraments is a fundamental moral theology and should be taken into account in the lecture on the fundamental principles of Christian morality, in other words, in the "principles."

\section{Theology of Human Life Response}

Showing the sublimity of the Christian vocation as the main task of moral theology ensures its theocentric character. It is aimed at the proper illumination of man's life response to God's call. For God's call demands an answer from man. This religious-moral response in the Christian "approach" is supposed to be, in turn, as stated, a subject of moral theology.

\section{Theological Anthropology}

In the category of vocation in Christ, not only is the approach of man to God characteristic of Christianity summarised, but also the Christian concept of man as an object of moral theology. Such an approach does not contradict a truth which is also recognizable independently of Revelation, that God is the Creator and the ultimate goal of man, and therefore the fundamental justification of our duty and moral norms. This is also a theological truth. In fact, however, it is important to consider man's relationship with God as an essential basis for theological-moral considerations that Scripture and dogmatic tradition do not know man ut sic; they only know man created in the image and likeness of God, man who lost the dignity of a child of God through sin, but was reconciled to God through the passion and death of Jesus Christ (cf. Rom 6:11; 2Cor 5:14); in the Sacrament of Baptism he was buried and resurrected together with Christ (cf. Rom 6:4f), freed from the necessity of sin (cf. Rom 6:6.22), to live on earth in the society of the People of God in anticipation of a new earth and a new heaven (cf. Ap 21:1). This reveals the biblical richness of the content of man's relationship with God as the basis for moral theology. Undoubtedly, the philosophically recognisable truth about man can be deduced from this set of truths, but how poor in comparison to what the revealed word of God tells us.

Moral theology examines the personality of man as the subject of response to God's call, and analyses the relevant properties and conditions of this response. The Council's postulate is to treat the doctrine of man and his activity properly within the framework of moral theology. As we know, so far this was limited to the problem of specific features of human activities. There is an 
urgent need for a comprehensive treatise on theological anthropology, taking into account the elements of nature and grace. The basis for such a treaty and its proper formulation can be found in the pastoral Constitution of the Second Vatican Council, in the chapter on the dignity of the human person (cf. GS 12-18) and on human activity in the world (cf. GS 33-39).

The Constitution Gaudium et spes points to the mystery of the Incarnate Word as a justification and a full explanation of Christian anthropology (cf. GS 22). It speaks of the paschal mystery as the source of the value of human activity (cf. GS 38), whose ultimate goal is a new earth and a new heaven (cf. GS 39). It shows the "model" of the new man in the form of Jesus Christ. He is the New Man, the Alpha and Omega of human society and the whole universe (cf. GS 45).

On the other hand, however, the Pastoral Constitution emphasises the value of "secular" human activity (cf. GS 34), the just autonomy of earthly things (cf. GS 36) and properly understood autonomy of natural cognition and scientific research (cf. GS 50, 62). These are valuable indications for the elaboration of a theological anthropological treatise on the basis of the revealed word of God, taking into account the natural knowledge and the current state of scientific research; with full respect for all that is in man, not only divine but also human. In this way, the postulate of only anthropocentricism in moral theology, which reveals the trait of Christian humanism, will be fulfilled.

\section{Theology of Freedom}

The question of Christian freedom is inextricably linked to the treaties on human dignity and human activity. This is a comprehensive treatise on the theology of freedom from the point of view of the moral life of a Christian who is called to freedom (cf. Gal. 5:13). A theological approach to the issue of freedom is not possible without showing the essential dependence of Christian freedom on the saving action of Jesus Christ. A comprehensive treaty on freedom takes on particular importance in view of the current issue of religious freedom. Guaranteeing this freedom and exercising it properly depends on a proper view of the essence of human freedom.

The Declaration on religious freedom of Vatican Council II affirms the natural right of the human to freedom from external coercion in religious matters. At the same time, however, he draws attention to the need for proper education to freedom (cf. DH 8). The Gaudium et spes (cf. GS 17.59.61) also stresses the need to educate people to exercise their freedom with a sense of responsibility. The same spirit revives recent decisions of the Congregation for the Doctrine of the Faith in connection with the abolition of the Church's index 
of forbidden books. They clearly draw attention to the need for knowledge and a sense of Christian responsibility with regard to the requirements of natural law ${ }^{15}$.

The documents of the Council's renewal show a tendency not to proliferate overly embarrassing regulations. This undoubtedly requires a sense of responsibility in exercising freedom and making a personal decision ${ }^{16}$. This reveals the need for a careful formation of conscience based on supernatural prudence. This indicates the timeliness and place of the treaties on conscience and prudence within moral theology. There is no doubt that, in the light of the Council's renewal, the importance of these treaties has increased enormously.

\section{Commitment to Love}

The task of moral theology is to correctly highlight the "duty to bring fruit in love for the life of the world" (OT 16). It must therefore make it clear that the fruit of the religious-moral life must be above all love for God and one's neighbour because it effectively ensures the "life of the world." This is related to the overcoming of individualism in the understanding of moral issues and the duties of the Christian life (cf. GS 30).

The Council's statement on moral theology clearly emphasises that the goal of the Christian life is not only personal perfection, but also concern for the "life of the world." Thus, moral theology must aim at overcoming the individualistic concept of morality. It should reveal the interconnectedness of the religious-moral life, which aims at the salvation of the individual with the life of the society of the People of God and of all humanity. It should not only draw attention to the social aspects of our work, but also show the duty of a positive commitment to the apostolate. It is a postulate resulting from the communal character of the vocation of man in God's plan (cf. LG 3; AA 2f; OP 6). However, apostolic activity must always be supported by the witness of life (cf. AG 15).

The "life of the world" is above all a supernatural salvation, which is achieved through life in the world. This requires a fair commitment to the

15 In the explanation to the decree abolishing the index we read: "Sive Notificado sive Decretum, cum fiduciam faciunt rectae conscientiae, vim legis naturalis confirmant. Magis igitur urget grave Ecclesiae officium fidelium conscientiae sollerter illuminandi ac recte formandi." Nota explicativa ad Decretum die 15 XI 1966, Nuntius S. Congrégations pro Doctrina Fidei, 1(1967)14.

16 The following expressions are noteworthy: "substantialis observantia," "complexus dierum," "pars notabilis," cf. Paulus VI, “Paenitemini," II, \$2, AAS 58(1966), 183; Sacra Congregatio Concilii, Dubium, AAS 59(1967), 229. 
affairs of this world. It is therefore necessary to demonstrate that the vocation in Christ also imposes an obligation to care for the creation of human and temporal values, and that it is in this way that the faithful bear fruit of their vocation (cf. LG 36; GS 34, 43; GE 2) ${ }^{17}$.

In the Council's statement it was clearly indicated that theology shows the duty to bear fruit for the life of the world "in love" (OT 16). In this way, the role of supernatural love as a source of dynamism in the Christian life is highlighted. In the life of supernatural love, the Christian mark of the pursuit of moral perfection through following Christ is manifested (cf. J 13:34; 15:10); moreover, by clinging to Jesus Christ (cf. Rom 13:14; Gal 3:27). Moral theology, according to the Council's indications, should therefore show the dynamism of the realisation of Christian vocation in expectation of the "blessed hope and the coming of the glory of God and our Saviour Jesus Christ" (Tit 2:13).

The dynamism of Christian love takes on a real form in a moral action enhanced by both acquired and implanted virtues. Acquired virtues ensure the operability of moral behaviour and thus their great significance for the moral life. The implanted ones improve human activity in the supernatural plane. The postulate of the renewal of the theological treatise on virtues is to reveal the place of the evangelical virtues of obedience, humility and patience in the concept of Christian morality. It is also necessary to show that an authentic Christian life above all by faith and supernatural hope. However, the most important aspect is love because in it a person gives over himself or herself, not just something that is his or her property.

The essential dependence of the dynamism of the Christian life on supernatural love raises the postulate of due consideration of the theology of love. It seems that the traditional treatise on the theological virtue of love within the framework of detailed moral theology does not fulfil this task. The theological approach to morality must make it clear that supernatural love is not only the greatest value and fundamental commandment, but above all the power that inspires the moral life of a Christian.

\section{Legal Issue}

To show the duty to bear fruit in love for the life of the world assumes the postulate of revealing the proper sources of moral obligation. It is not enough in this case to refer to the moral norms formulated in God's and ecclesiastical 
commandments. The basis of moral duty is the call of God and the gift of God to man which makes it possible to carry out a sublime vocation. In this way, the fruits of the Christian life are above all a revelation of the inner energies of the human soul under the guidance of the Holy Spirit, and not merely the result of obedience to a command (cf. Rom 7:5; 8:5-18; Gal 5:22f). However, moral theology, in the spirit of renewal, cannot ignore the question of moral law, since it shows the way for the proper development of religious-moral life.

The lecture on the theology of law in the spirit of the realisation of the Council's indications should reveal the personalistic features of the biblical approach to morality; the personal call to God and the human's response. Moral norms are an expression of the binding power of God's calling. In this way, the general norms serve a "dialogue" of morality between God and man. For they are the generalisation of God's will to call man to the religious and moral life. Through the norms of moral law, the voice of the calling God reaches us. In a specific case, the general rule becomes an "individual and personal call." Although God's will does not identify itself with the general norm formulated in the commandments, it is in these that it is expressed.

The theological and moral treatise on law must take due account of the relationship between supernatural values and natural values. This is a question of natural law because it manifests a moral aspect of the natural order. It is also necessary to point out the interdependence between the internal law of charity, which the Holy Spirit writes in the hearts of the faithful (lex interna), and the external prescriptions and norms which concretise the moral duty $(\text { lex externa })^{18}$. The doctrine of the law must not obscure the dynamism of Christian morality, which aims at the realisation of the sublime vocation in Christ.

Without neglecting the need to determine what is necessary in a concrete situation, we must not forget the universal vocation to holiness. The moral norm is to express a concrete task within the realisation of a vocation in life. The theology of law must therefore take into account the category of the call of God and the life response of man, in the conscious awareness that, because of the communal nature of vocation, man's response is to be carried out not only within the natural human community, but also in an organised and hierarchically ordered society of the People of God. 


\section{Conclusion}

In the analyses to date only the conciliar guidelines concerning the basic issues of moral theology have been considered. This does not mean at all that in the documents of the Council's renewal there are no indications on many issues that are simply discussed in the detailed part of moral theology. Such a subject is the issue of religious freedom, which is linked to the treaty on faith. The Council's postulate is also to discuss the problem of the priesthood of the faithful in connection with the treatise on the honour of God (de religione). Moral issues of dialogue and ecumenism, including the participation of Catholics in the religious life of other faiths (communicatio in sacris), are awaiting elaboration. The Council's guidelines for the moralistic theologian also refer to the issue of contemporary social life, which has become the subject of the second part of the Gaudium et spes Constitution and were developed by Paul VI in the encyclical Populorum progressio.

It seems superfluous to give a complete list of conciliar indications in the area of moral theology which relate to detailed topics of this theological discipline. In the Council's renewal of theology, it is not a question of seeking new content, but of showing the "old" truths and principles in a living relationship with the revealed word of God, taking into account the needs of the human race of our time. 